\title{
Teacher as a Guideline Learning in Early Children
}

\author{
Korlina Makulua ${ }^{1}$, Mersy F. Halamury ${ }^{2}$, Gerson Makulua ${ }^{3}$ \\ 1,2,3 IAKN Ambon, Ambon, Indonesia \\ $\left\{\underline{\text { kakomakulua@gmail.com }}{ }^{1}\right\}$
}

\begin{abstract}
Becoming an PAUD educator / teacher is not an easy thing for all people who work as educators to live. Early childhood is a unique person. The teacher is not only as an educator but also as a guide. The teacher should be able to understand and comprehend, be able to identify problems faced by children and be able to provide solutions to those problems. Such reality raises the problem What is the role of the teacher as a guide in early childhood learning? To answer this problem, a study was conducted by selecting the location: Taniwel Christian Kindergarten, Taniwel sub-district, West Seram district. The results showed that there were some things that stood out and there were some things that were weak in learning. The thing that stands out in the implementation of learning is patience, affection, attention, tolerance and empathy. While those who are weak in learning are friendly and full of warmth, and lack of freedom for children. Thus, it can be said that not all tutoring services at Taniwel Christian Kindergarten, run optimally.
\end{abstract}

Keywords: Teacher's Role, Guidance.

\section{Introduction}

\subsection{Background.}

Education is one of the most urgent things in a man's life, because education lasts throughout his life, from the womb until he dies, humans have never escaped what is called learning. Learning is a process of change that involves behavior or psychology. In learning psychology, process means specific ways or steps by which some changes are brought about to achieve certain results. So it can be interpreted as a learning process as a stage of cognitive, affective and psychomotor behavior changes that occur in students. The change is positive in the sense that it is oriented toward a more advanced direction than before. The teacher is the main party directly related to the child in the learning process effort, the teacher's role is inseparable from the existence of the curriculum.

Hurlock, said that the early development of a child (childhood) is more critical than the subsequent development. This is due to the continuous development of the child, meaning that the development of a stage will affect the development of the next stage, and the child's personality pattern develops to be relatively fixed. Children between 3 and 6 years of age develop rapidly in all aspects of development. Because this is a very important time, kindergarten education is very important for further child development.

The role of kindergarten teachers in the education process is very large. Kindergarten teachers are at least those who receive guidance / education in accordance with the level of child development so that they can optimize their development. During this period, there is a tremendous surge in children's development that does not occur in the next period. Teachers are required to be professional in carrying out their duties as a PAUD / TK educator, so that 
their role as a supervisor can be carried out properly. Basically, guidance is an effort to help individuals achieve optimal development. Development is a certain process that goes forward and cannot be repeated. therefore a PAUD / TK educator must pay attention to the patterns of guidance for early childhood.

\subsection{Formulation of the Problem}

The problem in this study is how the role of teacher guidance in early childhood learning in Taniwel Christian Kindergarten, Taniwel sub-district, West Seram district?

\subsection{Research Purposes}

This study aims to find out how the implementation of teacher guidance in learning in Taniwel Christian Kindergarten, Taniwel Sub-district, West Seram District, Taniwel SubDistrict, West Seram District.

\section{Methodology}

\subsection{The Nature of Guidance for Early Childhood}

Guidance is basically a guiding effort to help individuals achieve optimal development. According to Natawidjaja, providing understanding of guidance as a process of providing assistance to individuals is carried out on an ongoing basis, so that the individual understands himself, so he is able to direct himself and act appropriately, according to the demands and circumstances of the school, family, community, and life in general. Furthermore, there is also the definition of guidance proposed by Syaodih, that guidance in early childhood can be interpreted as an effort to help teachers to early childhood so that children can grow and develop optimally and be able to overcome the problems they face. Thus guidance is an aid in order to develop themselves, overcome problems or make decisions experienced by each child.

\subsection{The Purpose and Function of Guidance for Early Childhood}

The purpose of early childhood guidance in general is to develop the social-emotional skills and personality of children needed in order to develop themselves in accordance with their potentials so that it is useful for themselves and their communities.

On the other hand, the guidance function for early childhood is:

1. The function of understanding, namely the business of guidance that will produce an understanding of the child's self and their environment.

2. Prevention function, which is a guidance effort that results in the prevention of students from various problems that can hinder their development process

3. Repair function: guidance efforts that will result in the fragmentation of various problems faced by children

4. The function of maintenance and development: the guidance effort that results in the maintenance and development of a variety of positive potentials and conditions for students in order to develop themselves steadily and sustainably. 


\subsection{Characteristics of Early Childhood}

The characteristics of early childhood can be described as follows:

a) Have a great curiosity.

b) Is a unique person ...

c) Like to fantasize and imagine.

d) The most potential time for learning.

e) Showing egocentric attitude.

f) Has a short concentration power range.

g) As part of social beings.

Various academic characteristics possessed by early childhood as described above, are intended so that as early childhood educators need to know the characteristics of children so they can support development. They are optimally, especially in managing the learning process of early childhood (kindergarten).

\subsection{The Role of Teachers as Guides in AUD Learning}

The teacher is a source of inspiration and motivator for students in carving out their future. If the teacher can be a source of inspiration and motivator for their students then it will be the strength of students in pursuing their big ideals in the future. The word role refers to something that must be played or played. This means that the teacher's role is something that must be acted upon by the teacher like the actor while acting out the scene in accordance with the storyline that has been designed. In carrying out its role as a mentor, the teacher / assistant needs to have several characteristics. Syaodih, characteristics that must be possessed by a nursery are as follows:

\section{a) Be Patient}

Patience is a condition where the teacher / companion must be able to hold his emotions when dealing with a certain condition. For example, a teacher in early childhood education will deal with a variety of children's behavior and it may be found children who show pleasant behavior, children act arbitrarily or ank is very difficult to regulate in the classroom. Conditions like this may be able to provoke the teacher's emotion needs to have a high spread coupled with an understanding of the child's behavior at that time.

\section{b) Loving}

The teacher is a parent to the students. Early childhood is a relatively young child and still needs full affection from the parents. The need for love and a sense of security like what children get from parents is a condition that is also needed by children when children are in early childhood education institutions. A sense of affection can be manifested and felt by the child through a form of teacher / escort treatment to the child, such as not being angry at the child. children feel happy when they are near the teacher / assistant, always paying attention to the difficulties of children. 


\section{c) Attention}

Being attentive is another trait that the teacher / companion needs to have. Teachers / assistants need to pay attention and know the various changes that occur in children, both changes in abilities and behavior and behavior.

\section{d) Friendly}

Friendly nature is shown through behavior that is pleasing to others, sweet-faced not frowning or fierce. With a friendly sofat that is owned by a teacher / companion, children will feel happy and safe when dealing or being close to the teacher / companion. Conversely, if the teacher / companion is not friendly then the child will stay away and feel anxious and afraid when dealing with such teacher / companion.

\section{e) Empathy}

Empathy is a trait in which the teacher / companion can feel what is felt by his students. For example, when learning in class there are children who look depressed and are not eager to take lessons. The teacher will not let his students grieve, the teacher must approach the child and ask why he does not want to take lessons like his friends. Teachers who have warmth are characterized by the ability to create an atmosphere filled with excitement, free from fear and anxiety.

\section{f) Accept Children as They are}

Every child who studies in early childhood education is born from a different family and the child has its own characteristics. There are children who are born beautiful and adorable, but there are other children who are mediocre. There are children born with good cognitive abilities, but some are mediocre. An early childhood teacher / assistant cannot equate children and treats the same for all children because each child has different characteristics and abilities. The teacher needs to accept the child as he is with all the advantages and disadvantages.

\section{g) Fair}

Fair is another trait that must be owned by the teacher / assistant as a supervisor. A fair teacher is a teacher / assistant who does not discriminate against children, all children are the same.

\section{h) Understanding Children's Feelings}

The child is an individual who is still very unstable, the child's behavior is always influenced by his environment. If at one time the child's feelings are excited then the joy will be revealed by the child. conversely, if the child is feeling sad, the condition will also appear in the child's attitude. An early ank is innocent and spongy, what he feels will appear in his behavior. Psychological atmosphere experienced by children will affect how a child's behavior. if the teacher / companion faces the child in such an atmosphere, the teacher / 
companion should be able to understand the child's feelings. Through the child's attitude, the teacher can determine what steps can be taken to help overcome what is happening to the child.

\section{i) Forgiving of Children}

Forgiveness is a trait that is characterized by an attitude of no grudge against the attitudes of others. With forgiveness can grow understanding of the actions or abilities of the child. children sometimes show a pleasant attitude, but often also show an attitude that makes the teacher / assistant feel annoyed or exhausted. Facing such a child's attitude the teacher / companion must have forgiveness for the child, not have a grudge or resentment towards the child.

\section{j) Respect for Children}

A sense of respect is one aspect of the needs of every individual that needs to be understood including early childhood. No matter how small the ability or change shown by the child, teacher or companion must be able to appreciate it. Forms of appreciation can be given to children through expressions of gratitude for the behavior or services that have been done by children or giving rewards (awards) either verbal or nonverbal. Verbal awards such as saying "wow, how nice the picture", "very beautiful work today" or nonverbal awards by smiling, giving a thumbs up, patting the child's shoulders proudly. Appreciation like this will encourage children to show their better abilities later on.

\section{k) Give Freedom to Children}

Early childhood is a figure of individuals who have a very large curiosity, children have the nature of adventure and do not know fear. To facilitate the various characteristics possessed by early childhood, the teacher or companion needs to give freedom to the child to try, find, choose something according to their interests and needs.

\section{I) Creating Close Relationships with Children}

Facilitating the growth and development of children is one of the tasks that must be carried out by the teacher or companion of an early age. Children have the potential to develop both the potential associated with physical-motor, cognitive, language and social-emotional aspects. The teacher needs to create a close and pleasant relationship with the child in order to encourage the achievement of development as expected.

\section{Result and Discussion}

\subsection{Informant about the Role of Teachers}

The informant's understanding of the teacher's role as a mentor was very good. This was acknowledged by one of the informants who had the capacity as the principal. The other hand, the understanding of the informants is different, that to carry out the function as a supervisor has indeed been done by the teacher so far. This is due to several factors, including: the 
qualifications of teaching staff who on average have a high school diploma and the availability of educators who are not balanced with the number of students in Taniwel Christian Kindergarten. There are 3 educators in Taniwel Christian Kindergarten, including the Principal.

\subsection{Implementation of the Teacher's Role in Learning}

It was thro that really to carry out the task as a guide is not an easy thing. At least a teacher must master the techniques of implementing guidance for early childhood. The findings show that the supervisor's task must be carried out by someone who truly has a profession as a supervisor. To become a professional mentor requires certain educational qualifications. However, in reality the professional counselor for early childhood education does not yet exist so that the teacher or assistant also functions as a supervisor. Teachers or early childhood assistants do not have special educational guidance qualifications so that the handling of guidance is limited to helping the child's development and helping to overcome common problems experienced by students. When problems are found that are quite severe and need special treatment, the teacher or assistant needs to make a referral (outsourcing) to the psychiatrist, doctor, counselor or psychologist. The situation of the teacher in Taniwel Christian Kindergarten, A teacher or assistant does not have special qualifications as a guide, this causes the teacher or assistant to understand correctly about the concepts, scope, steps and guidance techniques that must be carried out.

In carrying out its function as a mentor, the time possessed by the teacher or assistant is very limited. Generally learning activities in early childhood education range from 2-3 hours per day, while teachers or assistants face children with relatively large numbers and diverse abilities. Students faced by teachers or facilitators are relatively small children. At this time the child has not been able to express the problem and overcome the problem so that the child is in dire need of teacher or companion intervention. Provision is limited as a guide in understanding the characteristics of early childhood and practically how to do so is one of the limitations of the teacher or companion as a guide. Problems with early childhood development always need joint handling between the teacher or assistant with the parents of the students. The limited ability to convey problems and collaborate in efforts to help overcome children's problems is an obstacle faced by early childhood teachers as mentors.

The findings as described above, indicate that in carrying out their role as a teacher's mentor many obstacles, not to mention the diverse characteristics of children, so special handling is needed not only by the teacher but also can build synergy with parents as the main educator in the family. In addition, parents are also required parental involvement in the process of mentoring and providing guidance for early childhood.

\section{Conclusion}

The teacher's role in learning has not been implemented well. It is expected that all kindergarten teachers are obliged to participate in activities that discuss or relate to the role of a teacher, so that the teacher can have a good understanding of how he acts. Because being a teacher is not an easy thing. 


\section{References}

[1] A. Rosdiana, 2002, Early Childhood Education as a Vehicle for Fundamentals of Life Skills Oriented Education ". In vision: Media for Study of Non-School and Youth Education. No. 12 / x / 2012

[2] HamalikOemar, 2009, Teacher Education Based on Competence, Jakarta, BumiAksara

[3] Haryanto \&Suyono 2011, Learning and Learning; Basic Theory and Concepts, Bandung,Rosdakarya Youth

[4] KosasihRaflis\&Soetjipto, 2009, Teaching Profession, Jakarta, Rineka copyrighted Lexy J. Moleong, Qualitative Research Methods, (Bandung: Youth Rosdakarya, 1989)(Yogyakarta: Tiara Wacana, 2000)

[5] MelatiRisang, 2012, Ways of Becoming a Successful PAUD Teacher That Children Like, Jogjakarta: Araska, page 23

[6] Rusman, 2011, Learning Model, Developing Teacher Professionalism, Jakarta, Raja Grafindo, Persada

[7] Salim Agus, Theory and Paradigm of Social Research from the Denzymes and their Application

[8] Sujiono Nurani, Yuliani 2009, Basic Concepts of Early Childhood Education, Jakarta, Index

[9] UdinSyaefudin Saud, 2012, Teacher Professional Development, Bandung, Alfabetha

Susanto Ahmad, 2012, Early Childhood Development, Introduction and Various Aspects, Second Edition, Jakarta, KencanaPrenada media Group 